НАУКОВИЙ ВІСНИК

Scientific messenger of Lviv National University of
Veterimary Medicicie and Biotechnologies

10

(5)

RIES: VETERINARY SCIEN
Науковий вісник Аьвівського національного університету ветеринарної медицини та біотехнологій імені С.3. Гжицького. Серія: Ветеринарні науки

Scientific Messenger of Lviv National University of Veterinary Medicine and Biotechnologies. Series: Veterinary sciences

UDC 616.995.428:636.2(477.53)

\title{
Distribution and features of chorioptosis of cattle as part of mixinvasions in farms of Poltava region
}

\author{
S. Kovalenko
}

Poltava State Agrarian University, Poltava, Ukraine

Article info

Received 18.10.2021

Received in revised form 19.11.2021

Accepted 20.11.2021

Poltava State Agrarian University, Skovorody Str., 1/3, Poltava 36003, Ukraine

Tel.:+38-067-979-45-09

E-mail:kovalennko97@ukr.net
Kovalenko, S. (2021). Distribution and features of chorioptosis of cattle as part of mixinvasions in farms of Poltava region. Scientific Messenger of Lviv National University of Veterinary Medicine and Biotechnologies. Series: Veterinary sciences, 23(104), 126-130. doi: 10.32718/nvlvet10420

Among ectoparasites that infect cattle, parasitic arthropods are the most common pathogens. These include acariform mites of the Chorioptes Bovis, which cause chorioptosis in ruminants. Parasitization of these permanent ectoparasites leads to significant losses in livestock due to reduced volumes and quality of industrial products. The study aimed to study the degree of infestation of cattle of different ages with the causative agent of chorioptosis in farms of Poltava region (Ukraine) and establish the features of acarosis in mixed invasions. Studies have shown that the average extent of chorioptosic invasion of cattle in the surveyed region was $16.80 \%$, and the moderate intensity of the invasion - 53.81 specimens of ticks on the body area of $4 \mathrm{~cm} 2$. It is proved that the indicators of infection of cattle Ch. Bovis grow with age. In calves, up to 6 months of age, young animals aged 6 to 12 months, heifers older than 12 months, and cows, the intensity of invasion was 9.40,15.24, 21.84, and $25 \%$, respectively, and the intensity of invasion was 16.73, $45,38,58.89$ and 78.61 specimens $/ 4 \mathrm{~cm} 2$. It was found that chorioptosis in cattle more often $(68.75 \%)$ occurs in the form of mixinvasions, where co-members of Chorioptes Bovis are parasitic insects (bovicols), cestodes (moniesies), trematodes (paramphistomes), nematodes (strongyloides, trichurises, strongylides of digestive organs) and coccidies (eimeries). Two-component mixinvasions were found in $65.91 \%$ of chorioptosis patients and three-component - in $25 \%$ of infected animals. Four-and five-component mixed invasions were less common (6.82\% and $2.27 \%$, respectively). A total of 19 species of mixed invasions were identified, 7 of which were two-component, 8 three-component, 3 four-component, and 1 fivecomponent. Simultaneous parasitization of Chorioptes Bovis and strongylide of digestive organs (25\%), bovicoles $(15.91 \%)$ in two-component mixinvasions was most often found. Other combinations of parasites were diagnosed less frequently (2.27-6.82 \%). The research results expand the already existing scientific data on the peculiarities of the chorioptosis of cattle and will allow us to take them into account when carrying out diagnostic and treatment-and-prophylactic measures for this invasion.

Key words: cattle, chorioptosis, distribution, mixinvasions, infestation rates.

\section{Поширення та особливості перебігу хоріоптозу великої рогатої худоби в складі мікстінвазій у господарствах Полтавського району}

\author{
С. О. Коваленко
}

Полтавський державний аграрний університет, м. Полтава, Украӥна

Серед ектопаразитів, щуо інвазують велику рогату худобу, паразитичні членистоногі є одними з найбільш поширених збудників. До їх числа відносять й акариформних клішів виду Chorioptes bovis, щчо викликають у жуйних тварин захворювання хоріоптоз. Паразитування цих постійних ектопаразитів призводить до значних втрат у тваринництві за рахунок зниження обсягів та якості продукції галузі. Метою роботи було вивчити ступінь інвазованості великої рогатої худоби різного віку збудником хоріоптозу в господарствах Полтавського району (Украӥна), а також встановити особливості перебігу акарозу в складі мікстінвазій. Проведеними дослідженнями встановлено, шьо середня екстенсивність хоріоптозної інвазії великої рогатої худоби в умовах обстежено- 
го регіону становила 16,80\%, а середня інтенсивність інвазї - 53,81 екземплярів клішів на діляниі тіла площею 4 см². Доведено, шзо з віком показники зараженості великої рогатої худоби Ch. bоvіs зростають. У телят віком до 6 місяців, молодняку віком від 6 до 12 місячів, телииь стариих 12 місячів та корів показники екстенсивності інвазї становили відповідно 9,40, 15,24, 21,84 та $25 \%$, а інтенсивності інвазї - 16,73, 45,38, 58,89 та 78,61 екз/4 см². Виявлено, шуо хоріоптоз у великої рогатої худоби частіше (68,75\%) перебігає у вигляді мікстінвазій, де співчленами Chorioptes bovis є паразитичні комахи (бовіколи), иестоди (монієзії), трематоди (парамфістоми), нематоди (стронгілоїдеси, трихуриси, стронгіліди органів травлення) та кокцидї (еймерії). Двокомпонентні мікстінвазії встановлено у 65,91\% хворої на хоріоптоз худоби, а трикомпонентні - у 25 \% інвазованих тварин. Рідше виявляли чотири - та п'ятикомпонентні мікстінвазії (6,82 \% та 2,27 \% відповідно). Всього виявлено 19 різновидів мікстінвазій, 7 з яких були двокомпонентні, 8 - трикомпонентні, 3 - чотирикомпонентні та 1 - п'ятикомпонентна. Найчастіше встановлено одночасне паразитування Chorioptes bovis та стронгілід органів травлення (25\%), бовікол (15,91\%) у двокомпонентних мікстінвазіях. Інші комбінації паразитів діагностували рідше (2,27-6,82\%). Отримані результати досліджень розщирюють вже існуючі наукові дані щзодо особливостей перебігу хоріоптозу великої рогатої худоби та дозволяють враховувати їх при проведенні діагностичних та лікувально-профілактичних заходів за даної інвазї.

Ключові слова: велика рогата худоба, хоріоптоз, поширення, мікстінвазї, показники інвазованості.

\section{Ветуп}

Забезпечення ветеринарного благополуччя щодо паразитарних хвороб є одним із факторів, яке впливає на можливість ефективного та рентабельного введення галузі тваринництва. Одним 3 поширених в усьому світі інвазійних захворювань великої рогатої худоби, що викликаються постійними ектопаразитами, $є$ хоріоптоз. Збудник належить до родини Psoroptidae, роду Chorioptes, виду Chorioptes bovis i відносяться до суворо специфічних паразитів (Beck et al., 2005; Lusat et al., 2011; Heath, 2021).

Наукова література свідчить, що хоріоптоз зареєстровано у великої рогатої худоби незалежно від їх породи, віку та способу утримання практично у всіх кліматичних зонах. Захворювання, викликане хоріоптесами, може набувати значного розповсюдження серед сприйнятливого поголів'я і завдає вагомих економічних збитків галузі (Rehbein et al., 2005; Kollbrunner et al., 2009; 2010). Акарозна інвазія перебігає гостро, підгостро або хронічно, характеризується запаленням шкіри, свербежем у місцях паразитування кліщів, випадінням волосся, виснаженням тварин, що в комплексі призводять до зниження їх продуктивності та племінної цінності (Rhodes, 1976; Shibata et al., 2003; Nematollahi et al., 2007).

Про значне поширення хоріоптозу великої рогатої худоби на території Бразилії свідчать науковці, які у 35,7 \% корів при дослідженні зіскобів зі шкіри виявили кліщів Ch. bovis (Vieira et al., 2014). В Ізраїлі науковці встановили, що показники екстенсивності хоріоптозної інвазії у великої рогатої худоби становили 80,5 \%. Причому корови виявилися найбільш ураженими хоріоптесами, де показник ЕI сягав 81,9 \%. Молодняк віком від 10 до 22 місяців був менш інвазованим кліщами, показники ЕІ коливалися від 6 до $12 \%$ (Rosen et al., 1989). Водночас, інші автори повідомляють, що у тварин старших 18-місячного віку хоріоптесів не виявлено, а інвазованість телиць до 18місячного віку склала 6 \% (Yeruham et al., 1981).

Дослідження, проведені в Нігерії встановили, що екстенсивність хоріоптозної інвазї великої рогатої худоби становила 25,4 \%. Причому, більш сприйнятливими до хоріоптесів виявилися тварини порід мбоpopo $(41,2 \%)$, гудалі $(26,0 \%)$, фулані суданська $(25,6 \%)$ та амбала $(18,8 \%)$, а також молодняк
(35,0 \%) порівняно 3 дорослою худобою (22,6 \%) (Biu \& Wakawa, 2004).

Тому важливим є встановлення епізоотологічних особливостей хоріоптозу великої рогатої худоби, що дозволить своєчасно та ефективно проводити профілактично-лікувальні заходи у господарствах та попередити економічні збитки. У зв'язку із вищезазначеним, метою роботи було вивчити ступінь інвазованості великої рогатої худоби різного віку збудником хоріоптозу в господарствах Полтавського району (Україна), а також встановити особливості перебігу акарозу в складі мікстінвазій.

\section{Матеріал і методи досліджень}

Роботу виконували упродовж 2020-2021 pр. на базі лабораторії кафедри паразитології та ветеринарносанітарної експертизи Полтавської державної аграрної академії та в умовах одноосібних селянських господарств Полтавського району (на території сіл: Абазівка, Андрушки, Івашки, Лаврики, Макарцівка, Макухівка, Патлаївка, Петрівка, Сем'янівка, Соснівка, Супрунівка, Тахтаулове, Уманцівка, Циганське).

У процесі обстеження тварин основним показником ураження великої рогатої худоби хоріоптесами була екстенсивність інвазії (ЕI, \%) та інтенсивність інвазії (II, екз/4 см²). Акарологічні дослідження зіскрібків зі шкіри проводили вітальними та мортальними методами згідно загальновідомих методик (Yuskiv, 1998; Yevstafieva \& Havryk, 2014; Yevstafieva et al., 2015). Виявляли кількість кліщів у зіскрібку з ділянки шкіри тіла розміром $2 \times 2 \mathrm{~cm}$.

Тварин уражених кліщами одночасно досліджували копроовоскопічно та оглядали шкіряний та волосяний покрив на наявність ектопаразитів (Galat et al., 2014).

Всього досліджено 381 голів великої рогатої худоби різного віку: молодняк до 6 міс., 6-12 міс., телиці старші 12 міс. та корови.

Математичний аналіз отриманих даних проводили 3 використанням пакету прикладних програм Microsoft "EXCEL". Розраховували середнє арифметичне (M) та його похибку (m).

\section{Результати та їх обговорення}

Проведеними дослідженнями встановлено, що середня екстенсивність хоріоптозної інвазії великої 
рогатої худоби в умовах Полтавського району становить $16,80 \%$, а інтенсивність інвазії $53,81 \pm 3,53$ екз/4 $\mathrm{cm}^{2}$ за коливань від 7 до 111 екз кліщів у зіскрібку.

Виявлено, що з віком тварин показники екстенсивності та інтенсивності хоріоптозної інвазії поступово зростають (табл. 1).

Зокрема, молодняк віком до 6 міс. був уражений найменше, показники ЕI та II відповідно становили $9,40 \%$ та $16,73 \pm 1,99$ екз/4 $\mathrm{cm}^{2}$. У молодняку віком від 6 до 12 місяців показники ЕI та II були вищими, ніж у телят до 6-місячного віку та відповідно становили $15,24 \%$ та 45,38 $\pm 4,84$ екз/4 см². У телиць старших 12-місячного віку показники ураженості хоріоптесами зростають до $21,84 \%$ та 58,89 $\pm 4,94$ екз/4 см відповідно. Найбільш інвазованими Ch. bovis виявилися корови, де ЕІ становила 25,00 \%, а II - 78,61 \pm 5,16 екз/4 $\mathrm{cm}^{2}$.

При вивченні особливостей перебігу хоріоптозу встановлено, що у 68,75 \% інвазованих тварин діагностовано одночасне паразитування хоріоптесів, бовікол, нематод, цестод, трематод та еймерій. Тільки у 31,25 \% великої рогатої худоби діагностовано хоріоптозну моноінвазію. Частіше виявляли двокомпонентні мікстінвазії (65,91\%), рідше три-, чотири- та п'ятикомпонентні мікстінвазії (25\%, 6,82 \% та 2,27 \% відповідно) (рис. 1).

Всього виявлено 19 різновидів мікстінвазій, 73 яких були двокомпонентні, 8 - трикомпонентні, 3 чотирикомпонентні та 1 - п'ятикомпонентна (табл. 2).

\section{Таблиця 1}

Ураженість великої рогатої худоби різного віку Chorioptes bovis

\begin{tabular}{lcccc}
\hline Вік тварин & Досліджено, гол & Інвазовано, голів & ЕІ, \% & $\begin{array}{c}\text { II, екз } / 4 \mathrm{~cm}^{2} \\
\text { M m }(\min -\mathrm{max})\end{array}$ \\
\hline Молодняк до 6 міс. & 117 & 11 & 9,40 & $\begin{array}{c}16,73 \pm 1,99 \\
(7-27)\end{array}$ \\
Молодняк 6-12 міс. & 105 & 16 & 15,24 & $\begin{array}{c}45,38 \pm 4,84 \\
(20-78)\end{array}$ \\
Телиці старше 12 міс. & 87 & 19 & 21,84 & $\begin{array}{c}58,89 \pm 4,94 \\
(21-104)\end{array}$ \\
Корови & 72 & 18 & 25,00 & $\begin{array}{c}78,61 \pm 5,16 \\
(39-111)\end{array}$ \\
\hline
\end{tabular}

хоріоптозна моноінвазія п мікстінвазії

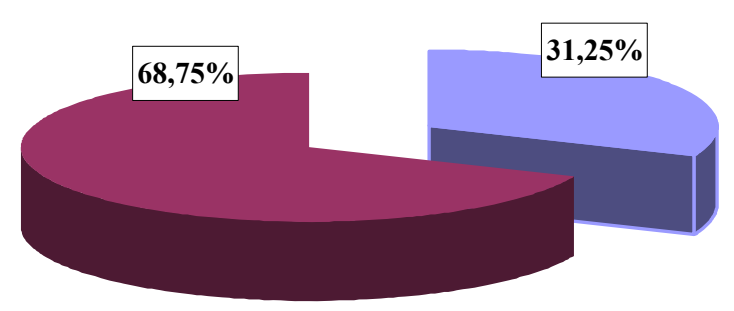

a 2-компонентні 3-компонентні 4-компонентні 5-компонентні

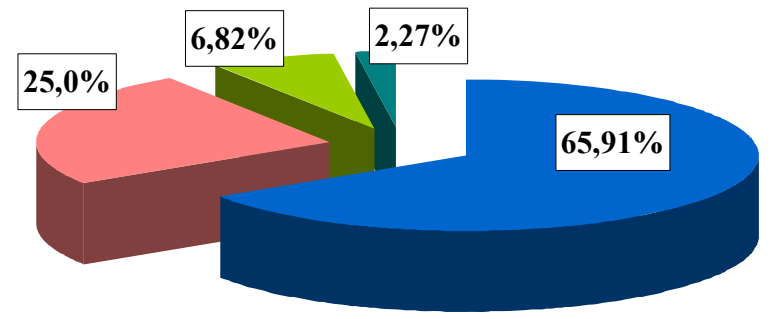

$\mathrm{b}$

Рис. 1. Форми перебігу хоріоптозу у великої рогатої худоби: а - відсоткове співвідношення хоріоптозної моноінвазії та у складі мікстінвазій; b - відсоткове співвідношення різнокомпонентних мікстінвазій

Таблиця 2

Різновиди мікстінвазій за хоріоптозу великої рогатої худоби

\begin{tabular}{|c|c|c|c|}
\hline Види мікстінвазій & $\begin{array}{c}\text { Інвазовано, } \\
\text { голів }\end{array}$ & $\begin{array}{c}\text { \% від } \\
\text { мікстінвазій } \\
(\mathrm{n}=44)\end{array}$ & $\begin{array}{c}\text { \% від хворих на } \\
\text { хоріоптоз } \\
(\mathrm{n}=64) \\
\end{array}$ \\
\hline Двокомпонентні: & 29 & 65,91 & 45,31 \\
\hline хоріоптеси + еймерії & 3 & 6,82 & 4,688 \\
\hline хоріоптеси + стронгіліди органів травлення & 11 & 25,00 & 17,19 \\
\hline хоріоптеси + стронгілоїдеси & 3 & 6,82 & 4,688 \\
\hline хоріоптеси + трихуриси & 3 & 6,82 & 4,688 \\
\hline хоріоптеси + монієзії & 1 & 2,27 & 1,563 \\
\hline хоріоптеси + парамфістоми & 1 & 2,27 & 1,563 \\
\hline хоріоптеси + бовіколи & 7 & 15,91 & 10,94 \\
\hline
\end{tabular}




\begin{tabular}{lccc}
\hline Трикомпонентні: & 11 & 25,00 & 17,19 \\
хоріоптеси + еймерії + стронгіліди органів травлення & 1 & 2,27 & 1,563 \\
хоріоптеси + трихуриси + бовіколи & 2 & 4,55 & 3,125 \\
хоріоптеси + стронгіліди органів травлення + стронгілоїдеси & 1 & 2,27 & 1,563 \\
хоріоптеси + трихуриси + парамфістоми & 2 & 4,55 & 3,125 \\
хоріоптеси + стронгілоїдеси + бовіколи & 2 & 4,55 & 3,125 \\
хоріоптеси + трихуриси + монієзії & 1 & 2,27 & 1,563 \\
хоріоптеси + еймерії + монієзії & 1 & 2,27 & 1,563 \\
хоріоптеси + стронгіліди органів травлення + бовіколи & 1 & 2,27 & 1,563 \\
\hline Чотирикомпонентні: & 3 & 6,82 & 4,688 \\
хоріоптеси + еймерії + стронгілоїдеси + трихуриси & 1 & 2,27 & 1,563 \\
хоріоптеси + еймерії + стронгілоїдеси + бовіколи & 1 & 2,27 & 1,563 \\
хоріоптеси + трихуриси + бовіколи + монієзії & 1 & 2,27 & 1,563 \\
\hline П'ятикомпонентні: & 1 & 2,27 \\
хоріоптеси + стронгіліди органів травлення + стронгілоїдеси + & 1 & 2,27 \\
бовіколи + монієзії & 1,563 \\
\hline
\end{tabular}

3 двокомпонентних найчастіше реєстрували одночасне паразитування хоріоптесів та збудників стронгілідозів органів травлення ( $25 \%$ від мікстінвазій), а також бовікол (15,91\%). Інші асоціації хоріоптесів та еймерій, стронгілоїдесів, трихурисів, монієзій та парамфістом діагностували рідше (2,27-6,82 \%). 3 трикомпонентних виявляли хоріоптозно-трихурознобовікольозну $(4,55 \%), \quad$ хоріоптозно-трихурознопарамфістоматидозну $(4,55 \%), \quad$ хоріоптозностронгілоїдозно-бовікольозну $(4,55 \%)$, хоріоптозноеймеріозно-стронгілідозну $(2,27 \%), \quad$ хоріоптозностронгілідозно-стронгілоїдозну (2,27\%), хоріоптознотрихурозно-монієзіозну $(2,27 \%), \quad$ хоріоптозноеймеріозно-монієзіозну $(2,27 \%)$ та хоріоптозностронгілідозно-бовікольозну $(2,27 \%)$ мікстінвазії. Чотирикомпонентні мікстінвазії були представлені хоріоптесами, еймеріями, стронгілоїдесами, трихурисами, бовіколами i монієзіями (2,27\%). П'ятикомпонентна мікстінвазія характеризувалася одночасним паразитуванням в організмі великої рогатої худоби хоріоптесів, стронгілід органів травлення, стронгілоїдесів, бовікол і монієзій $(2,27 \%)$.

Наукова література свідчить про значне поширення хоріоптозу великої рогатої худоби у різних країнах світу. Автори доводять, що дана інвазії призводить до значних економічних збитків у тваринництві (Faccini \& Massard, 1976; Reddy et al., 1992; Yeruham et al., 1991; Nematollahi et al., 2007). Результати наших досліджень показали, що середня екстенсивність хоріоптозної інвазії серед поголів'я великої рогатої худоби у господарствах Полтавської області становила $16,80 \%$, а інтенсивність інвазії - 53,81 $\pm 3,53$ екз/4 см ${ }^{2}$ площі шкіри тіла тварини. Причому виявлено, що 3 віком худоби показники їх інвазованості хоріоптесами поступово зростають і сягають максимальних значень у продуктивних корів, де показники екстенсивності та інтенсивності інвазії відповідно становили $25,00 \%$ та $78,61 \pm 5,16$ екз/4 см². Отримані нами дані узгоджуються з результатами досліджень окремих авторів, які встановили, що екстенсивність інвазії хоріоптесами корів сягала $81,9 \%$, а молодняку - від 6 до $12 \%$ (Rosen et al., 1989).

Також, результатами проведених досліджень виявлено, що хоріоптоз у великої рогатої худоби частіше $(68,75 \%)$ перебігає у вигляді мікстінвазій, де співчленами Chorioptes bovis є бовіколи, монієзії, парамфістоми, стронгілоїдеси, трихуриси, стронгіліди органів травлення та еймерії. Всього виявлено 19 різновидів мікстінвазій, 7 з яких були двокомпонентні (65,91\% від мікстінвазій), 8 - трикомпонентні (25\%), 3 - чотирикомпонентні $(6,82 \%)$ та 1 п'ятикомпонентна $(2,27 \%)$. Є повідомлення, де у альпаки (Huacaya alpaca) встановлено одночасне паразитування у тварин хоріоптесів, саркоптесів, протостронгілід та дикроцелій (Castilla-Castano et al., 2021).

Отримані результати досліджень розширюють вже існуючі наукові дані щодо особливостей перебігу хоріоптозу великої рогатої худоби та дозволяють враховувати їх при проведенні діагностичних та лікувально-профілактичних заходів за даної інвазії

\section{Висновки}

Встановлено, що середня екстенсивність інвазії за хоріоптозу великої рогатої худоби у господарствах Полтавського району становила $16,80 \%$, а інтенсивність інвазії $-53,81 \pm 3,53$ екз $/ 4 \mathrm{~cm}^{2}$. У тварин з віком показники зараженості Chorioptes bovis поступово зростають, де найбільш ураженими є корови (ЕI $25 \%$, II - 78,61 $\pm 5,16$ екз/4 см²). В умовах дослідженого регіону хоріоптоз у $68,75 \%$ інвазованих тварин перебігає у вигляді мікстінвазій, де співчленами хоріоптесів є бовіколи, парамфістоми, монієзії, стронгілоїдеси, трихуриси, стронгіліди органів травлення та еймерії Кількість співчленів у мікстінвазіях коливається від двох до п'яти, де частіше виявляли двокомпонентні асоціації Ch. bovis зі збудниками стронгілідозів органів травлення $(25 \%)$ та бовікольозу $(15,91 \%)$. 
Перспективи подальших досліджень. Перспективами подальших досліджень $є$ вивчення терапевтичної ефективності сучасних інсектоакарицидних препаратів за хоріоптозу великої рогатої худоби.

\section{References}

Beck, W., Pfister, K., \& Weiland, G. (2005). Epidemiologische erhebungen zur Chorioptes-räude des rindes in Deutschland [Epidemiological investigations of bovine Chorioptes mange in Germany]. Berliner und Munchener Tierarztliche Wochenschrift, 118(3-4), 128-133. URL: https://pubmed.ncbi.nlm.nih.gov/15803760.

Biu, A. A., \& Wakawa, M. M. (2004). Chorioptic mange infestation in cattle in Borno State, Nigeria. Pakistan Veterinary Journal, 24(3), 155-156.

Castilla-Castano, E., Herman, N., Martinelli, E., Lecru, L. A., Pressanti, C., Schelcher, F., \& Cadiergues, M. C. (2021). Treatment of sarcoptic and chorioptic mange in an alpaca (Vicugna pacos) herd with a combination of topical amitraz and subcutaneous ivermectin. New Zealand Veterinary Journal, 69(2), 121-126. doi: 10.1080/00480169.2020.1808544.

Cornall, K., \& Wall, R. (2015). Ectoparasites of goats in the UK. Veterinary Parasitology, 207(1-2), 176-179. doi: 10.1016/j.vetpar.2014.11.005.

Faccini, J. L. H., \& Massard, C. L. (1976). O genero Chorioptes Gervais, 1895, parasita de ruminantes no Brasil (Psoroptidae, Acarina). Revista Brasileira de Biologia, 36, 871-872.

Galat, V. F., Berezovskyj, A. V., Soroka, N. M., Prus, M. P., Yevstafieva, V. O., \& Galat, M. V. (2014). Globalna parazytologija. Kyiv: DIA (in Ukrainian).

Heath, A. (2021). Climate change and its potential for altering the phenology and ecology of some common and widespread arthropod parasites in New Zealand. New Zealand Veterinary Journal, 69(1), 5-19. doi: 10.1080/00480169.2020.1787276.

Kollbrunner, M., Luginbühl, A., \& Pfister, K. (2010). Epidemiologische aspekte zur Chorioptes-Räude bei milchkühen in der Schweiz: eine felduntersuchung [Epidemiological aspects of Chorioptes-mange in dairy cows in Switzerland: a field study]. Schweizer Archiv fur Tierheilkunde, 152(5), 231-236. doi: 10.1024/0036-7281/a000054.

Kollbrunner, M., Pfister, K., \& Luginbühl, A. (2009). Chorioptes-Räude bei milchkühen: eine neue einschätzung als basis für die bekämpfung [Chorioptic mange in dairy cattle: a new assessment for its control]. Berliner und Munchener Tierarztliche Wochenschrift, 122(9-10), 358-363. doi: $10.2376 / 0005-9366-122-358$.
Lusat, J., Bornstein, S., \& Wall, R. (2011). Chorioptes mites: re-evaluation of species integrity. Medical and Veterinary Entomology, 25(4), 370-376. doi: 10.1111/j.1365-2915.2011.00951.x.

Nematollahi, A., Moghaddam, G. A., \& Golezardy, H. (2007). An outbreak of Chorioptes bovis mange on a dairy farm in Tabriz, Iran. Iranian Journal of Veterinary Research, 8(4), 351-354. doi: 10.22099/ijvr.2007.26.

Reddy, N. R. J., Murthy, C., Souza, P. E. D., Jagannath, M. S., \& Rao, P. M. (1992). Generalised chorioptic mange in a cow - a case report. Indian Veterinary Journal, 69, 547-549.

Rehbein, S., Winter, R., Visser, M., Maciel, A. E., \& Marley, S. E. (2005). Chorioptic mange in dairy cattle: treatment with eprinomectin pour-on. Parasitology Research, 98(1), 21-25. doi: 10.1007/s00436-005-0005-y.

Rhodes, A. P. (1976). The effect of extensive chorioptic mange of the scrotum on reproductive function of the ram. Australian Veterinary Journal, 52(6), 250-257. doi: 10.1111/j.1751-0813.1976.tb00100.x.

Rosen, S., Yeruham, I., \& Hadani, A. (1989). Chorioptes texanus (Hirst, 1924), Psoroptidae on cattle in Israel. Acarologia, 30, 373-376. URL: https://www1.montpellier. inrae.fr/CBGP/acarologia/article.php?id=2497.

Shibata, A., Yachimori, S., Morita, T., Kanda, E., Ike, K., \& Imai, S. (2003). Chorioptic mange in a wild Japanese serow. Journal of Wildlife Diseases, 39(2), 437-440. doi: 10.7589/0090-3558-39.2.437.

Vieira, M. I., Bordin, T., Dall'Agnol, B., Zanchin, F., Motta, A. C., \& Noro, M. (2014). Re-emergence of Chorioptes bovis (Acari: Psoroptidae) in cattle in the state of Rio Grande do Sul, Brazil. Brazilian Journal of Veterinary Parasitology, 23(4), 530-533. doi: 10.1590/S1984-29612014090.

Yeruham, I., Hadani, A., Sklar, A., \& Monbaz, A. (1981). The occurrence of chorioptic mange in dairy cattle in Israel. Refuah Veterinarith, 38, 176-179.

Yeruham, I., Hadani, A., \& Rosen, S. (1991). Chorioptic mange (Chorioptes bovis Hering, 1845) in sheep in Israel and its control with ivomec. Israel Journal of Veterinary Medicine, 46, 148-149.

Yevstafieva, V. O., \& Havryk, K. A. (2014). Udoskonalennia metodiv zazhyttievoi diahnostyky sarkoptozu, otodektozu ta demodekozu sobak. Visnyk Poltavskoi Derzhavnoi Ahrarnoi Akademii, 4, 62-64. doi: 10.31210/visnyk2014.04.11 (in Ukrainian).

Yevstafieva, V. O., Havryk, K. A., \& Havryk, B. A. (2015). Rekomendatsii shchodo diahnostyky ta zakhodiv borotby $\mathrm{z}$ akarozamy sobak. Poltava (in Ukrainian).

Yuskiv, I. D. (1998). Akarolohichni doslidzhennia tvaryn ta akarytsydy. Lviv: Kameniar (in Ukrainian). 